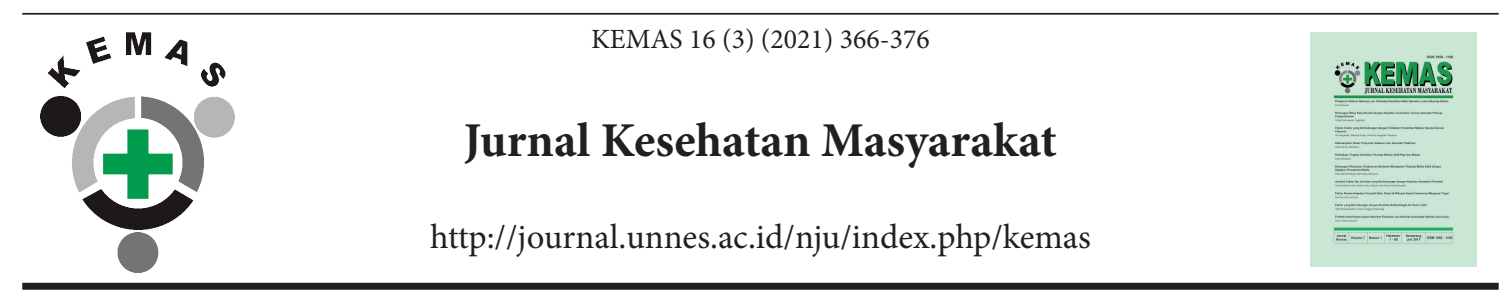

\title{
The Early Vigilance of Dengue Hemorrhagic Fever Outbreak in the Community
}

\author{
Rachmah Indawati $^{1 凶}$, Lucia Yovita Hendrati ${ }^{2}$, and Sri Widati ${ }^{3}$ \\ ${ }^{1}$ Departement of Biostatistics and Population Study, Public Health School of Airlangga University, Campus \\ C Faculty of Public Health, Airlangga University \\ ${ }^{2}$ Departement of Epidemiology, Public Health School of Airlangga University, Campus C Faculty of Public \\ Health Airlangga University \\ ${ }^{3}$ Departement of Health Promotion and Health Behaviour, Public Health School of Airlangga University, \\ Campus C Faculty of Public Health, Airlangga University
}

\section{Article Info}

Article History:

Submitted April 2020

Accepted July 2020

Published March 2021

\section{Keywords:}

Dengue hemorrhagic

fever, Outbreak, Early

awareness, Community

\section{DOI}

https://doi.org/10.15294/

kemas.v16i3.24114

\begin{abstract}
Early Awareness of Extraordinary Events of Dengue Hemorrhagic Fever (DHF) was asked to community $(n=130)$. Precautions were measured based on community knowledge, attitudes, and behavior. Knowledge, attitude, and behavior are constructs (in the form of a composite variable) from an early awareness of DHF outbreak. The result showed that the knowledge related to the transmission factor and the proliferation of dengue disease was quite good $(72.3 \%)$. The DHF risk control was also good (93.9\%) while the dengue fever eradication was still poor (67.7\%). However, the attitude showed that it is still not ready to act on the basis of consciousness. Meanwhile, the results of the data analysis identified that the model of the early awareness measurement on DHF outbreak which consisted of construct variables (knowledge, attitude, and action) were a perfect fit. Based on the measurement model, the level of community awareness on DHF disease can be measured. This showed that the level of early awareness of DHF disease was good $76.2 \%$ and only $3.8 \%$ were less alert. This means although the less alert percentage is quite small, if people have an attitude of indifference to the prevention of DHF then the impact will affect a wider community.
\end{abstract}

\section{Introduction}

The community knowledge about dengue hemorrhagic fever (DHF) is already good, yet the case of DHF is still high. The cases is frequent occurrence of sporadic at urban area (Bhatt et al., 2013). The research evidence showed that there is a relationship between knowledge, attitudes, and actions related to dengue disease (Febryana et al., 2010; Pujiyanti and Trapsilowati, 2010; Shuaib et al., 2010; Aryati, Sali and Aryasih, 2014; Lontoh, Rattu and Kaunang, 2016; Kenneson et al., 2017; Harapan et al., 2018; Ghani et al., 2019) and is determined by ability a vector to transmit a pathogen (Zaki et al., 2019).

The dengue fever cases in some districts and cities in East Java has continue to increase.
In the Pasuruan city, the spread of dengue fever case has increased. This situation caused Pasuruan City in 2010 amounted to $85.3 \%$ (29 urban villages out of 34 urban villages) are DHF endemic village. These areas are Karangketug, Gadingrejo, and Sekargadung. So, among 8 Public Health Center, almost all (70\%) have endemic villages. Public Health Center in Trajeng and Kandangsapi is the only area that does not have endemic villages. In addition, the indicator of free number of larvae in all working areas of Public Health Center in 2013 is still below target (Dinas Kesehatan Pasuruan, 2015). Early awareness of DHF is the vigilance to potentially extraordinary diseases (outbreak) by applying epidemiological surveillance that is utilized to improve preparedness and response 
stance quickly and appropriately. The quick and responsive attitude of the community is very important to monitor the possibility of DHF outbreaks (Eldigail et al., 2018).

The eradication of infectious diseases is still a threat to human life. Given the problem of dengue fever is still increasing, early vigilance against dengue fever is needed; and for it to be reliable, it requires psychological measurement models. Psychological measurements include knowledge, attitudes and behaviors that are extracted based on indicators developed in the community. Knowledge of dengue fever, awareness and preventive measures are strategies for early vigilance. To be able to conduct early vigilance, one's need to understand the disease symptoms and risk factors; have the willingness/ability to act; and observe restrictions and controls. Furthermore, the measurement model can be used to obtain information on eradicating disease.

The objective was to create an early vigilance measurement model for DHF described as a dimension of the psychological function (knowledge, attitude and behavior/ action). The expected benefit of the citizen who has a high level of vigilance was that they tend to proactively respond to the environment that has dengue disease potential. The opinions of the community on the concept of vigilance can affect the psychological function in a positive or negative manner.

\section{Method}

This research was an observational research conducted by cross-sectional. The sample was a family in Pasuruan. The technique used to take the data was cluster random sampling technique and the sample was 130 families. Data was collected through interviews using structured questionnaires. Operational definition: 1) Knowledge of DHF risk is a community understanding of the symptoms and risk factors for dengue transmission.
Indicators used include the factors of dengue fever transmission, dengue fever reproduction area, and disease control measures. The measurements used Likert scale $1=$ do not know anything - 5= know very well about the risk of DHF. Interval data scale; 2) Attitude to $\mathrm{DHF}$ is something that is in the mind related to the dengue disease. The indicators used include how to respond to DHF. The measurements used Likert scale $1=$ unresponsive - 5= highly responsive. Interval data scale; 3 ) Practice of $\mathrm{DHF}$ is an action that is done related to risk control (cleaning mosquito breeding place) and eradication of DHF (efforts to eliminate mosquitoes). The measurements used Likert scale $1=$ very inaction $-5=$ very good acts to control / eradicate dengue. Interval data scale; 4) Early vigilance is measured by psychological function. The results of the total score are then categorized ( $1=$ less, $2=$ enough, $3=$ alert, $4=$ very alert). Ordinal data scale.

Data analysis procedures in this study were carried out in several stages. There are 3 parts: to describe descriptively by exposing the characteristics of society using frequency distribution table. Pearson correlation analysis were used to test the validity and reliability of the instrument. The Second-Order Confirmatory Factor Analysis (2ndCFA) to get the model measurement. The results of testing the validity and reliability of the instrument; Validity of data was measured by looking at Pearson correlation coefficient. If the value $r>$ 0.6 , it is not negative and meaningful with $p$ value $<0.05$. The data reliability was measured by looking at Chronbach alpha $>0.6$ indicating that the instrument was reliable. The Pearson correlation results showed that the relationship between item-total scores in each factor (knowledge, action) was valid ( $r>0.6)$. The value of Chronbach alpha> 0.6 indicated that the instrument was reliable. While the attitude that was only measured on a single item considered as valid and reliable. 
Table 1. Validity and Reliability of Psychological Functions on Early Awareness of DHF Outbreaks

\begin{tabular}{lccl}
\hline & Item-total score $(\mathbf{p}$ value) & Reliability & Explanation \\
\hline Knowledge & & 0.662 & Valid \\
Factors of transmission & $0.905(0.0001)$ & & Reliable \\
Breeding & $0.772(0.0001)$ & & \\
How to control the disease & $0.766(0.0001)$ & - & Valid \\
Attitude* & - & & Reliable \\
& & 0.641 & Valid \\
Behavior / action & & & Reliable \\
Risk control & $0.892(0.0001)$ & & \\
Eradication & $0.874(0.0001)$ & & \\
\hline
\end{tabular}

${ }^{*}$ measured on 1 single item

Analysis of 2ndCFA to get the model measurement of early awareness of DHF outbreak by taking into account overall model testing, measuring model validity and model reliability. Overall model matching test, indicating that the value of Goodnessof-Fit Index (GFI), Adjusted Goodness of Fit Index (AGFI), Normed Fit Index (NFI), dan Comparative Fit Index (CFI) was good $(\geq 0.9)$, $\mathrm{RMR} \geq 0.5$. The validity of the measurement model, the standard factor load value $\geq 0.5$, then all factors in the model were fit. Reliability of measurement model, the standard factor load data, and error could be obtained from the diagram. The values of Construct Reliability $(\mathrm{CR}) \geq 0.7$ and Variance Extracted (VE) $\geq 0.5$ indicated that the reliability of the measurement model was good.

\section{Result and Discussion}

Community characteristics are measured based on sociodemographic variables, namely age, sex, and education. The average age of the community is 41.8 years with an age range of 21-77 years. By the age group, most of the correspondence is at the age of 41-50 years (36.2\%). Most of the correspondence is women with 125 people $(96.2 \%)$ and the men are 5 people (3.8\%). Most of them are an unemployed housewife that is 98 people $(75.4 \%)$. According to the level of education, $32.4 \%$ have completed primary school education and $31.5 \%$ have completed high school education while $10 \%$ do not finish primary school. Education level identifies that most people have basic education.

The results of identification showed that the average age of 41.8 years was a mature age. This means that people had a good ability in thinking and acting in order to overcome the extraordinary events of dengue in the community. Basic education is very important for someone to be able to read and write. People who can read and write are assumed to have a good understanding and have a positive attitude and can deal with a certain case in order to involve in a simple DHF eradication program.

Table 2. Distribution of Age and Education Level of Community in Pasuruan City

\begin{tabular}{lll}
\hline Variable & Frequency $(\mathbf{n}=\mathbf{1 3 0})$ & Percentage $\mathbf{( \% )}$ \\
\hline Age group (years old) & & \\
$21-30$ & 23 & 18.0 \\
$31-40$ & 35 & 27.3 \\
$41-50$ & 47 & 36.2 \\
$51-60$ & 21 & 16.4 \\
$>60$ & 4 & 3.1 \\
Education level & & \\
Unfinished elementary school & 13 & 10.0 \\
Elementary school & 42 & 32.4 \\
Junior high school & 23 & 17.6 \\
Senior high school & 41 & 31.5 \\
University & 11 & 8.6 \\
\hline
\end{tabular}


Sociodemographic characteristics provide an important role in involvement in disease control. Based on age, psychologically mature age groups are more able to receive health information and have management of ways to prevent disease. Basic education that has been undertaken in most societies within this mature age groups can be oriented to positive health problems. They can also make efforts to control disease. Control is carried out not only at home but also the environment around where they live. Evidence shows that there is a positive relationship between education and knowledge about dengue (Zameer et al., 2013). Meanwhile, the results of other studies show that people who have knowledge will be able to make a difference as the beginning of making a change (Lacsina, Caranto and David, 2015).

This research shows that the majority of public opinion is correct regarding mosquito breeding and mosquito habitat. Community understanding about the symptoms and risk factors of dengue fever was quite good at $72.3 \%$ while the number of people who did not completely understand about this issue was less than $17.7 \%$ and only $10 \%$ of community has good knowledge. The community knowledge about the breeding of mosquito eggs to mosquito larvae varied between 1-30 days (98.4\%) while those who did not know was $1.6 \%$. The knowledge about larvae transformation to mosquitoes varied between 1-30 days (97.7\%) while who said do not know was $2.3 \%$. The knowledge of mosquitoes transformation into adult mosquitoes laying eggs varied between 1-60 days (97.7\%) and who said that they did not know was $2.3 \%$.

Furthermore, the understanding of the mosquito hiding place was in the hidden place like below the chair or bed (41\%), in the dark place was 7 people $(5.5 \%)$, in the sewer or the puddle was 12 people $(9.4 \%)$, in the flower vase was 4 people (3.1\%), and the rest of correspondence mentioned other places such as shoe rack, leaves, and shrubs was 20 people (15.6\%), and as many as $44(34.4 \%)$ said that they did not know. The results of the interviews showed that the community's understanding of the causes of DHF was a less clean environment. This unclean environment was caused by scattered waste and unavailability of trash cans.
"The lifestyle that is not clean ....... dispose of waste inappropriately." (U) "Throw garbage recklessly, lots of stagnant water. That is because of faith factor. "( $G)$

Garbage was also discharged into rivers and sewers causing ditches and rivers to be inundated. Moreover, SPAL (water drainage system) that was not routinely cleaned exacerbated environmental conditions in Pasuruan. The garbage causing the drains or water channels clogged so that puddles arose that became a breeding ground for mosquitoes. In addition to household waste, residents often dispose livestock manure in the river. In addition to clogging the flow of the river, this dirt also causes odor. Moreover, some residents still defecate in the river causing pollution and unpleasant odors. This situation is exacerbated by the unspecified time of garbage worker in collecting the garbage. In fact, mostly, it takes a long time to finally transport the garbage. As a result, there are a lot of garbage piles and more mosquitos in this place. In addition to waste disposal behavior, the behavior of put items in the house that is not tidy, like hanging clothes also become one of the factors causing the number of Aedes Aegypti mosquitoes in Pasuruan. Here are the interview results:

"The most difficult is the habit of hanging clothes ......." (N)

Hanging clothes are identified as behaviors that are perceived as common and often done by the population. This lack of precaution has been shown to be at risk for mosquito breeding (Pratamawati, 2012). There is no relationship between knowledge and attitudes towards prevention and no relationship between knowledge and behavior on the prevention of DHF (Pujiyanti and Trapsilowati, 2010). The house arrangement that was less clean and neat was also pointed out as the cause of the number of mosquitoes nesting and hiding. Often the house was not designed in such a way that allows sunlight to enter. Damp and no light causes mosquitoes to stay in the house. Moreover, the residents resided together with a high enough density. This level of density causes the structuring of the environment is not tidy and mosquito can create nest easily. Some residents also became 
collectors of scrap. These items are widely used by mosquitoes to hide. Especially if the home owner does not care about health or hygiene. In fact, population density has been associated with dengue transmission (Schmidt et al., 2011; Padmanabha et al., 2012; Pratamawati, 2012; Prasetyani, 2015).

Public understanding of the symptoms and risk factors of transmission and the way of dengue fever breed was quite good. People also understand about mosquito hiding places. However, this understanding was not followed by good attitude and behavior. Based on the empirical evidence there were still many people who did not keep the environment clean, including outside or inside their house. Moreover, based on the evidence, the link between knowledge and attitude or knowledge and behavior showed that there was no significant difference (Pujiyanti, Pratamawati and Trapsilowati, 2016; Kurniawan et al., 2017).

Knowledge is still considered as an important factor to understand ways to reduce the increase and control of disease vectors. Even knowledge is predicted as an advantage in taking preventative action (Al-Dubai et al., 2013; Ho et al., 2013). The attitude of the community is measured in the form of responses on how to respond to DHF. Community attitudes in the prevention of DHF were still limited to government programs. For example, citizens only do DHF prevention if there was instruction for community services.

"......, there are funds from PNPM (governance) to close all of the open ditch ....... Advice from the city mayor." (F)

The results of identification showed that people were not ready to act on the ground of consciousness despite knowing the risks posed by this disease. Attitude is a response to conditioned social circumstances. Individual knowledge and attitudes reveal outputs that can identify one's vulnerability to be infected by a virus. Individual attitudes cannot be seen but can be presented in the form of a willingness to act. Furthermore, good knowledge and a positive attitude are forms of action to control the disease. The condition of endemic areas is also a factor that must be considered as a strategy to control the viruses with the aim of reducing the risk of contracting. According to research evidence, one way that can help to reduce vulnerability is by allocating resources and considering the location of the environment (Castro et al., 2013).

Risk control is an effort to take action. Community actions in cleaning breeding sites and trying to eliminate mosquitoes. Most communities (66.9\%) had open containers that can hold water and $33.1 \%$ did not have open containers. For the frequency of the community in cleaning up places that were considered as a breeding ground for mosquitoes, $93.9 \%$ said that the bathroom tub was cleaned between every day to once a week. And $6.1 \%$ said that they clean the bathroom tub between two weeks to once a month. The disease may reflect the diverse socioeconomic of the populations (Torres et al., 2017).

Table 3. The Distribution of Risk Control Measures and Dengue Eradication in Pasuruan City

\begin{tabular}{lll}
\hline Behavior / Action & $\begin{array}{l}\text { Frequency } \\
(\mathbf{n}=130)\end{array}$ & $\begin{array}{l}\text { Percentage } \\
(\%)\end{array}$ \\
\hline Risk control & & \\
Less & 8 & 6.1 \\
$\quad$ Good & 122 & 93.9 \\
Eradication of DHF & & \\
$\quad$ Less & 88 & 67.7 \\
Enough & 32 & 24.6 \\
Good & 10 & 7.7 \\
\hline
\end{tabular}

The results showed that the community's actions in controlling the mosquito breeding by cleaning the place or container that can be used as a breeding mosquito have been very good. However, this was not an easy task for most people so more than half of the community did not routinely clean the mosquito reservoir container. This has been supported by the research that the vector control by the community was still low (Waris and Yuana, 2013; Alma, 2014; Pujiyanti and Pratamawati, 2014; Suryanegara, Suparmi and Setyaningrum, 2018).

According to research evidence, ecological changes can be seen from mosquito breeding sites, developing social culture, people's behavior and lifestyle (Vijayakumar et al., 2014). Therefore, this requires preventive measures. This risk control is a community 
behaviour to manage the environment and try not to let it become a breeding ground for mosquitoes. Community action in eradicating disease is done through family efforts to reduce the number of mosquitoes and spraying. The efforts by the family to eliminate mosquitoes was less than $67.7 \%$ and the family action in the eradication of DHF was only $7.7 \%$. Through a deep interview, community action toward DHF cases showed that when people were affected by DHF, people had a quick respond to hospitalization. They also reported to local cadres.

"Every case of Dengue Fever directly informs the cadres ... .. it will be followed up by reporting to the community health center and the community health center will follow up by reporting to the Health Office." (NH)

The results of identification proved that despite the society already had a good knowledge about mosquito breeding but they still had improper attitude in controlling mosquitoes. Things that play an important role in this negative attitude come from their own personal character and society. From their own character, Most of people were lazy to tidy up their stuff while the society itself tend to be ignorant with the environment. Taking action in risk control and dengue eradication was not easy. The research evidence suggested that preventive efforts (implementing mass spraying prior to the season of transmission of Dengue Hemorrhagic disease at the endemic areas) were in fact being overshadowed by outbreaks of DHF (Tairas, Kandou and Posangi, 2015). In addition, the effect of increasing individual mobility between regions, or the rapid expansion of disease vectors in areas previously thought to be non-endemic areas, requires action to improve disease control and observation programs. The study states that the effective measure to control dengue still lies in precautions taken by individuals (Cheng et al., 2018).

A lot of effort need to be done to be free from the DHF risks. In addition, extra time and funds is needed to clean the open shelter. It can be assumed that it is almost impossible for residents living in slums to do all of that effort. With a life that is far from decent, dengue control is not a priority. So, Community believes that the eradication of DHF is the government responsibility (health sector). Research evidence shows that control of dengue fever is the responsibility of the government (Zameer et al., 2013; Otu et al., 2019). In addition, the evidence from the study of the relationship between disease vectors and the environment, especially the container where mosquitoes breed, is basically strongly influenced by socioeconomic conditions, shelter and individual behavior such as water storage practices (Tun-Lin et al., 2009; Banu et al., 2011; Quintero et al., 2014; Overgaard et al., 2017).

Community vigilance is a responsive attitude and fast action in the prevention of DHF. Level of vigilance was seen from the total score of the psychological function. The data showed that the level of DHF awareness was good enough at $76.2 \%$, the percentage of people who had good vigilance level was $7.7 \%$, very good vigilance level was $12.3 \%$, and the lessvigilance community was only $3.8 \%$. Although less vigilance percentage was quite small if these community groups had a reluctant attitude toward prevention of DHF, for example, if they were uncaring with the environment then it will impact the wider community.

The obstacles in tackling dengue found from the interviews were some obstacles in dealing with dengue problems. Among this problem was incomplete Community Health Center equipment so that the public must relay to the Hospital. There was also a Community Health Center that was only for treatment and can not diagnose whether someone had positive or negative DHF. The issue which was not less important was the length of case reporting from the hospital to the health office and then from the health office to the Public Health Center so that the handling of the outbreak seems to be slow.

\footnotetext{
"In some cases, communities are quite responsive by directly doing hospitalization for high fever patient. Communities hope the Health Department to act immediately for fogging." ( $\mathrm{T}$ )

In the 2nd CFA analysis, the hypothesized
} 
model is the early awareness of DHF outbreak as the main construct. This construct has three sub-constructs namely knowledge, attitude and action. Here are the results of the analysis: 1). Overall model matching test, shows that GFI value $=0.96, \mathrm{NFI}=0.96, \mathrm{AGFI}=0.88, \mathrm{CFI}=$ 0.97 is $\operatorname{good}(\geq 0.9), \mathrm{RMR}=0.5,2)$. The validity of the measurement model shows that the standard factor load value $\geq 0.5$. This means that then all factors in the model are fit, and

Table 4. The Results of Validity and Reliability of Early Vigilance Measurement Model

\begin{tabular}{|c|c|c|c|c|c|}
\hline \multirow{2}{*}{ Variable } & \multirow{2}{*}{$\begin{array}{l}\text { Standard Factor } \\
\text { Load } \geq 0.5\end{array}$} & \multirow{2}{*}{ Error } & \multicolumn{2}{|c|}{ Reliabilities } & \multirow[t]{2}{*}{ Explanation } \\
\hline & & & $\mathrm{CR} \geq \mathbf{0 . 7}$ & $\mathrm{VE} \geq 0.5$ & \\
\hline \multicolumn{6}{|l|}{$1^{\text {st }}$ CFA } \\
\hline Knowledge & & & 0.86 & 0.67 & Good reliability \\
\hline Transmission factor & 0.73 & 0.47 & & & Validity is good \\
\hline Breeding & 0.88 & 0.23 & & & Validity is good \\
\hline Disease proliferation method & 0.84 & 0.30 & & & Validity is good \\
\hline Attitude & 1 & 0.00 & & & Valid \& Reliable \\
\hline Behavior / action & & & & & Good reliability \\
\hline Risk control & 0.81 & 0.35 & & & Validity is good \\
\hline Eradication & 0.58 & 0.66 & & & Validity is good \\
\hline \multicolumn{6}{|l|}{$2^{\text {nd }}$ CFA } \\
\hline Early precautions & & & 0.76 & 0.52 & Good reliability \\
\hline Knowledge & 0.72 & 0.49 & & & Validity is good \\
\hline Attitude & 0.72 & 0.48 & & & Validity is good \\
\hline Behavior / action & 0.72 & 0.48 & & & Validity is good \\
\hline
\end{tabular}

3). Reliability of measurement model, standard factor load data, and error can be obtained from the diagram. The values of $\mathrm{CR} \geq 0.7$ and $\mathrm{VE} \geq 0.5$. This indicates that the reliability of the measurement model is good.

Figure 1. It shows the fit between the final model and the empirical data. This model illustrates that the early awareness of DHF outbreaks has three constructs namely knowledge, attitude and behavior. Knowledge has three dimensions (the factors of transmission, breeding, and breeding method); Attitudes have one indicator and the behavior has two dimensions (DBD risk control and DHF eradication).

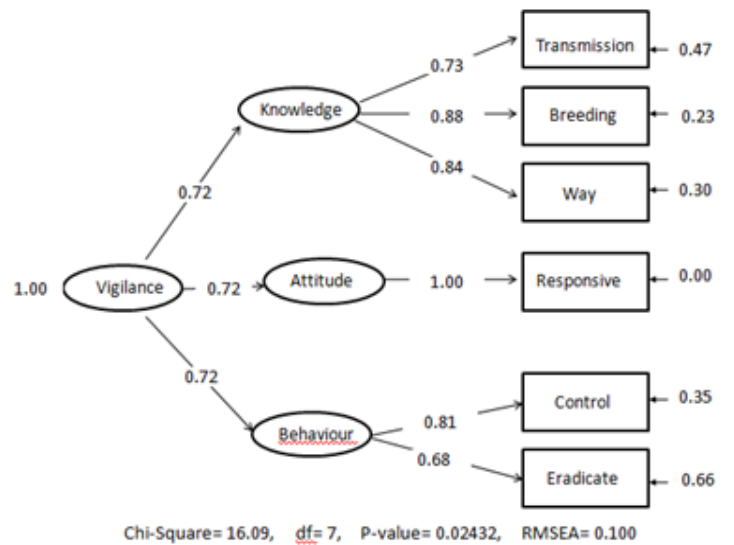

Chi-Square $=16.09, \quad d f=7, \quad$-value $=0.02432, \quad$ RMSEA $=0.100$
Figure 1. Early vigilance measurement model of extraordinary incidence of DHF

Based on the results, there was difference opinion between the program managers and the community. As a result, community tend to be apathy in responding to dengue case. Fogging as the solution when there was dengue case was contrary to the program (considering the mosquito will be adaptable and resistant to the drug). In fact, based on the research, one of the causes of the high rate of dengue fever was due to the weak early awareness system (Pratamawati, 2012) and the awareness of outbreaks of DHF should be implemented by supervising the implementation of duties and authority of health officials at central and local government level (Sinaga, 2015).

So based on the empirical results, it indicates that the desire of the community is a curative action while the government related to the preventive aspects. Based on these circumstances, it is necessary for the government to provide information related to drug resistance if given continuously (on every case) or excessively. Without controlling and maintaining good environmental conditions, dengue cases will continue to be a public health problem. In the end, the community 
itself must have a positive attitude towards the environment by maintaining the environment. Information needs to be given in preventing dengue fever either for the community or health care (Lacsina, Caranto and David, 2015). The primary public health intervention is the reduction in mosquito breeding habitat and through a public education program (Guerdan, 2010; Yussof et al., 2017). Another effort to consider by the government is by developing a geographic information system to control outbreaks of DBD.

The model illustrates that the early awareness of DHF outbreaks has three constructs namely knowledge, attitude and behavior. The theory of health behavior states that the knowledge obtained about a disease gives benefits to individuals to have positive attitude. This is an initial advantage in preventing the disease. Next step is to act by paying attention to the social and health point of view, which involves the community to actively participate in controlling dengue fever. Several studies have suggested that community participation is a strategy in prevention and control (Arunachalam et al., 2012; Dick et al., 2012; Tapia-Conyer, Méndez-Galván and Burciaga-Zúñiga, 2012; Dhimal et al., 2014; Fernández-Salas et al., 2015; Alvarado-Castro et al., 2017). Whereas several other studies have found conflicting results between the incidence of dengue and the knowledge, attitude and behavior of a population. Nevertheless, the relationship in psychological theory must still be built as a prevention strategy (Bowman, Runge-Ranzinger and McCall, 2014; Carabali et al., 2015; Telle et al., 2016; Fuentes-Vallejo, 2017).

\section{Conclusion}

Knowledge was measured by 3 indicators, attitudes were measured by one indicator and behavior was measured by 2 indicators and it was a valid and reliable measure. The community understanding on the factors of transmission and dengue fever was quite good. Action on risk control was also good (93.9\%) but dengue eradication was still less good $(67.7 \%)$. Attitudes showed that they were not yet ready to act on the basis of consciousness. The psychological function was the component of early awareness of DHF outbreaks. The results of the measurement model showed a significant statistical value. The vigilance level of DHF outbreaks was sufficient.

\section{References}

Al-Dubai, S.A.R., Ganasegeran, K., Rahman, A.M., Alshagga, M.A., \& Saif-Ali, R., 2013. Factors Affecting Dengue Fever Knowledge, Attitudes And Practices Among Selected Urban, Semi-Urban And Rural Communities In Malaysia. Southeast Asian Journal of Tropical Medicine and Public Health, 44(1), pp.37-49.

Alma, L., 2014. The influence of the Status of Residence and PSN DBD Behavior on the Existence of Larvae in Sekaran Village, Semarang City. Unnes Journal of Public Health, 3(3), pp.1-9.

Alvarado-Castro, V., Paredes-Solís, S., NavaAguilera, E., Morales-Pérez, A., AlarcónMorales, L., Alejandra Balderas-Vargas, N., \& Andersson, N., 2017. Assessing The Effects of Interventions for Aedes Aegypti Control: Systematic Review and Meta-Analysis of Cluster Randomised Controlled Trials. BMC Public Health, 17(Suppl 1), pp.1-18.

Arunachalam, N., Tyagi, B.K., Samuel, M., Krishnamoorthi, R., Manavalan, R., Tewari, S.C., Ashokkumar, V., Kroeger, A., Sommerfeld, J., \& Max Petzold., 2012. Community-Based Control of Aedes Aegypti by Adoption of Eco-Health Methods in Chennai City, India. Pathogens and Global Health, 106(8), pp.488-496.

Aryati, I.K.C., Sali, I.W., \& Aryasih, I.G.A.M., 2014. Relationship between Knowledge of Attitudes and Actions of Society with the Incidence of Dengue Hemorrhagic Fever (DHF) in Baler Bale Agung Village, Negara District, 2012. Journal of Environmental Health, 4(2), pp.118-123.

Banu, S., Hu, W., Hurst, C., Tong, S., 2011. Dengue Transmission in The Asia-Pacific Region: Impact of Climate Change and SocioEnvironmental Factors. Tropical Medicine and International Health, 16(5), pp.598-607.

Bhatt, S., Gething, P.W., Brady, O.J., Messina, J.P., Farlow, A.W., Moyes, C.L., Drake, J.M., Brownstein, J.S., Hoen, A.G., Sankoh, O., Myers, M.F., George, D.B., Jaenisch, T., Wint, G.R.W., Simmons, C.P., Scott, T.W., Farrar, J.J., \& Hay, S.I., 2013. The Global Distribution and Burden of Dengue. HHS Public Access, 496(7446), pp.504-507. 
Bowman, L.R., Runge-Ranzinger, S., \& McCall, P.J., 2014. Assessing the Relationship Between Vector Indices and Dengue Transmission: A Systematic Review of The Evidence. PLoS Neglected Tropical Diseases, 8(5), pp.1-11.

Carabali, M., Hernandez, L.M., Arauz, M.J., Villar, L.A., \& Ridde, V., 2015. Why Are People With Dengue Dying? A Scoping Review of Determinants for Dengue Mortality. BMC Infectious Diseases. BMC Infectious Diseases, 15(301), pp.1-14.

Castro, M., Sánchez, L., Pérez, D., Sebrango, C., Shkedy, Z., \& der-Stuyft, P.V., 2013. The Relationship Between Economic Status, Knowledge on Dengue, Risk Perceptions and Practices. PLoS ONE, 8(12), pp.1-6.

Cheng, Y.H., Lin, Y.J., Chen, S.C., You, S.H., Chen, W.Y., Hsieh, N.H., Yang, Y.F., \& Liao, C.M., 2018. Assessing Health Burden Risk and Control Effect On Dengue Fever Infection In The Southern Region of Taiwan. Infection and Drug Resistance, 11, pp.1423-1435.

Dhimal, M., Aryal, K.K., Dhimal, M.L., Gautam, I., Singh, S.P., Bhusal, C.L., \& Kuch, U., 2014. Knowledge, Attitude and Practice Regarding Dengue Fever Among The Healthy Population of Highland and Lowland Communities in Central Nepal. PLoS ONE, 9(7), pp.1-15.

Dick, O.B., Martín, J.L.S., Montoya, R.H., del-Diego, J., Zambrano, B., \& Dayan, G.H., 2012. Review: The History of Dengue Outbreaks in The Americas'. American Journal of Tropical Medicine and Hygiene, 87(4), pp.584-593.

Dinas Kesehatan Pasuruan, 2015. Profil Kesehatan Kota Pasuruan 2014. Pasuruan.

Eldigail, M.H., Adam, G.K., Babiker, R.A., Khalid, F., Adam, I.A., Omer, O.H., Ahmed, M.E., Birair, S.L., Haroun, E.M., Aisha, H.A., Karrar, A.E., Abdalla, H.S., \& Aradaib, I.E., 2018. Prevalence of Dengue Fever Virus Antibodies and Associated Risk Factors Among Residents of El-Gadarif State, Sudan. BMC Public Health, 18, pp.1-8.

Febryana., Apriyanti, H., Pradysta, M.K., Anindyajati, G., Karunia, A.P.P, Emy., 2010. Comparison of Knowledge, Attitudes and Behaviors Regarding Dengue Fever between Sosromenduran and Pringgokusuman Villages, Gedongtengen District, Kodia Yogyakarta. Community Medical News, 26(2), pp.100-106.

Fernández-Salas, I., Danis-Lozano, R., CasasMartínez, M., Ulloa, A., Bond, J.G., Marina, C.F., Ordóñez, T.L., Elizondo-Quiroga, A., Torres-Monzón, J.A., Díaz-González,
E.E., 2015. Historical Inability to Control Aedes Aegypti as A Main Contributor of Fast Dispersal of Chikungunya Outbreaks In Latin America. Antiviral Research, 124, pp.30-42.

Fuentes-Vallejo, M., 2017. Space And Space-Time Distributions of Dengue In A HyperEndemic Urban Space: The Case of Girardot, Colombia. BMC Infectious Diseases, 17, pp.512-528.

Ghani, N.A., Shohaimi,S., Hee, A.K., Chee, H., Emmanuel, O., \& Ajibola, L.S.A., 2019. Comparison of Knowledge, Attitude, and Practice Among Communities Living in Hotspot and Non-hotspot Areas of Dengue in Selangor, Malaysia. Tropical Medicine and Infectious Disease, 4(37), pp. 1-10.

Guerdan, B.R., 2010. Dengue Fever/Dengue Hemorrhagic Fever. American Journal of Clinical Medicine, 7(2), pp.51-53.

Harapan., Rajamoorthy, Y., Anwar, S., Bustamam, A., Radiansyah, A., Angraini, P., Fasli, R., Salwiyadi., Bastian, R.A., Oktiviyari, A., Akmal, I., Iqbalamin, M., Adil, J., Henrizal, F., Darmayanti., Pratama, R., Setiawan, A.M., Mudatsir., Hadisoemarto, P.F., Dhimal, M.L., Kuch, U., Groneberg, D.A., Imrie, A., Dhimal, M., \& Müller, R., 2018. Knowledge, Attitude, and Practice Regarding Dengue Virus Infection Among Inhabitants of Aceh, Indonesia: A Cross-sectional Study. BMC Infectious Diseases, 18(96), pp.1-16.

Ho, T., Huang, M., Wang, S., Hsu, H., Liu, C., 2013. Knowledge, Attitude, and Practice of Dengue Disease Among Healthcare Professionals In Southern Taiwan. Journal of the Formosan Medical Association, 112(1), pp.18-23.

Kenneson, A., Beltrán-Ayala, E., Borbor-Cordova, M.J., Polhemus, M.E., Ryan, S.J., Endy, T.P., \& Stewart-Ibarra, A.M., 2017. Social-Ecological Factors and Preventive Actions Decrease The Risk of Dengue Infection at The HouseholdLevel: Results From A Prospective Dengue Surveillance Study in Machala, Ecuador. PLoS Neglected Tropical Diseases, 11(12), pp.1-19.

Kurniawan, M.E., Mohamed, A.M.D., Siyam, N., Fatikha, N., \& Fitriani, N.A., 2017. Relation Between Knowledge And Attitude Regarding DHF With PSN Behavior Among The Community Around The Campus. Jurnal Kesehatan Masyarakat, 13(2), pp.145-151.

Lacsina, J.I.B., Caranto, L.C., \& David, J.J.T., 2015. Plague Ground: Healthcare Management of Dengue / Dengue Hemorrhagic Fever. International Journal of Nursing Science, 
5(3), pp.103-109.

Lontoh, R., Rattu, A.J.M., \& Kaunang, W.P.J., 2016. The Relationship Between Knowledge and Attitude With Dengue Hemorrhagic Fever (DBD) Prevention Measures in Village of Malalayang 2 Environment III. PharmaconPharmaceutical Scientific Journal, 5(1), pp.382-389.

Otu, A., Ebenso, B., Etokidem, A., \& Chukwuekezie, O., 2019. Dengue Fever - An Update Review and Implications for Nigeria, and Similar Countries. African Health Sciences, 19(2), pp.2000-2007.

Overgaard, H.J., Olano, V.A., Jaramillo, J.F., Matiz, M.I., Sarmiento, D., Stenström, T.A., \& Alexander, N., 2017. A Cross-sectional Survey of Aedes Aegypti Immature Abundance in Urban and Rural Household Containers in Central Colombia. Parasites and Vectors. Parasites \& Vectors, 10(356), pp.1-12.

Padmanabha, H., Durham, D., Correa, F., DiukWasser, M., \& Galvani, A., 2012. The Interactive Roles of Aedes Aegypti SuperProduction and Human Density in Dengue Transmission. PLoS Neglected Tropical Diseases, 6(8), pp.1-11.

Prasetyani, R.D., 2015. Factors Associated with Dengue Hemorrhagic Fever. Journal Majority, 4(7), pp.61-66.

Pratamawati, D.A., 2012. The Role of Larva Monitors in the Dengue Hemorrhagic Fever Early Alert System in Indonesia. Journal of National Public Health, 6(6), pp.443-248.

Pujiyanti, A., \& Pratamawati, D., 2014. Dengue Hemorrhagic Fever Vector Control in Elementary School Communities in Tembalang District, Semarang City. Journal of Vektora, 6(2), pp.46-51.

Pujiyanti, A., Pratamawati, D.A., \& Trapsilowati, W., 2016. The Relationship of Knowledge, Attitudes, and Behaviors in Controlling DBD Vector in Elementary School Students in Tembalang District, Semarang City. Health Research and Development Media, 26(2), pp.85-92.

Pujiyanti, A., \& Trapsilowati, W., 2010. Knowledge, Attitudes and Behavior of Housewives in Dengue Hemorrhagic Fever Prevention in Kutowinangun Village, Salatiga. Journal of Vektora, 2(2), pp.102-115.

Quintero, J., Brochero, H., Manrique-Saide, P., Barrera-Pérez, M., Basso, C., Romero, S., Caprara, A., Cunha, J.C.D.L., BeltránAyala, E., Mitchell-Foster, K., Kroeger, A., SommerfeldJ., \& Petzold, M., 2014.
Ecological, Biological and Social Dimensions of Dengue Vector Breeding in Five Urban Settings of Latin America: A multi-Country Study. BMC Infectious Diseases, 14(38), pp.1-13.

Schmidt, W., Suzuki, M., Thiem, V.D., White, R.G., Tsuzuki, A., Yoshida, L., Yanai, H., Haque, U., Tho, L.H., Anh, D.D., \& Ariyoshi., K., 2011. Population Density, Water Supply, and The Risk of Dengue Fever in Vietnam: Cohort Study and Spatial Analysis. PLoS Medicine, 8(8), pp.1-10.

Shuaib, F., Todd, D., Campbell-Stennett, D., Ehiri, J., \& Jolly, P.E., 2010. Knowledge, Attitudes and Practices Regarding Dengue Infection in Westmoreland, Jamaica. West Indian Med J, 59(2), pp.139-146.

Sinaga, S.N., 2015. Policies for Dengue Fever Management in Indonesia. Scientific Journal of Scientific Research, 1(1), pp.1-7.

Suryanegara, F.D., Suparmi, S., \& Setyaningrum, N., 2018. The Description of Larva Free Index as COMBI (Communication for Behavioral Impact) Dengue Hemorrhagic Fever Prevention Indicator. Jurnal Kesehatan Masyarakat, 13(3), pp.338-344.

Tairas, S., Kandou, G., \& Posangi, J., 2015. Analysis of the Implementation of Dengue Hemorrhagic Fever Control in North Minahasa District. JIKMU, 5(1), pp.21-29.

Tapia-Conyer, R., Méndez-Galván, J., \& BurciagaZúñiga, P., 2012. Community Participation In The Prevention and Control of Dengue: The Patio Limpio Strategy in Mexico. Paediatrics and International Child Health, 32(SUPP1), pp.10-13.

Telle, O., Vaguet, A., Yadav, N.K., Lefebvre, B., Daudé, E., Paul, R.E., Cebeillac, A., Nagpal, B.N., 2016. The Spread of Dengue In An Endemic Urban Milieu-The Case of Delhi, India. PLoS ONE, 11(1), pp.1-17.

Torres, J.R., Orduna, T.A., Piña-Pozas, M., VázquezVega, D., \& Sarti, E., 2017. Epidemiological Characteristics of Dengue Disease in Latin America and in the Caribbean: A Systematic Review of the Literature. Journal of Tropical Medicine, 2017, pp.1-18.

Tun-Lin, W., Lenhart, A., Nam, V.S., Rebollar-Téllez, E., Morrison, A.C., Barbazan, P., Cote, M., Midega, J., Sanchez, F., Manrique-Saide, P., Kroeger, A., Nathan, M.B., Meheus, F., \& Petzold, M., 2009. Reducing Costs and Operational Constraints of Dengue Vector Control by Targeting Productive Breeding Places: A Multi-Country Non-Inferiority Cluster Randomized Trial. Tropical Medicine 
and International Health, 14(9), pp.11431153.

Vijayakumar, K., Kumar, T.K.S., Nujum, Z.T., Umarul, F., \& Kuriakose, A., 2014. A Study on Container Breeding Mosquitoes With Special Reference to Aedes (Stegomyia) Aegypti and Aedes albopictus in Thiruvananthapuram District, India. Journal of Vector Borne Diseases, 51(1), pp.27-32.

Waris, L., \& Yuana, W., 2013. Community Knowledge and Behavior on Dengue Hemorrhagic Fever in Batulicin District, Tanah Bumbu Regency, South Kalimantan Province. Journal of Epidemiology and Animal Sourced Diseases, 4(3), pp.144-149.

Yussof, F.M., Hassan, A., Zin, T., Hussin, T.M.A.R., Kadarman, N., \& Umar, R., 2017. Knowledge of Dengue Among Students in Universiti Sultan Zainal Abidin (UNISZA), Terengganu,
Malaysia and the Influence of Knowledge of Dengue on Attitude and Practice. Journal of Fundamental and Applied Sciences, 9(2S), pp.199-216.

Zaki, R., Roffeei, S.N., Hii, Y.L., Yahya, A., Appannan, M., Said, M.A., Wan, N.C., Aghamohammadi, N., Hairi, N.N., Bulgiba, A., Quam, M., \& Rocklov, J., 2019. Public Perception and Attitude Towards Dengue Prevention Activity and Response to Dengue Early Warning in Malaysia. PLoS ONE, 14(2), pp.1-22.

Zameer, M., Shuja, M., Ashraf, A., Mukhtar, N., Ahmad, B.M., 2013. Knowledge, Attitudes and Practices Study of Dengue Viral Infection and Its Association with Environmental Factors and health Issues, Lahore Pakistan. African Journal of Environmental Science And Technology, 7(7), pp.711-717. 